\title{
A Symbolic Reading of Wide Sargasso Sea
}

\author{
Li Luo \\ China West Normal University, Sichuan, Nanchong, China
}

\begin{abstract}
Wide Sargasso Sea is acclaimed as the masterpiece of the British female writer Jean Rhys. In the novel, Rhys reshapes the mad wife of Rochester, Bertha Mason, who is imprisoned in the attic in Jane Eyre. With her own life experience as a white Creole and her experience living in West Indies as a blueprint, setting the abolition of slavery in West Indies in the nineteenth century as the background of the times, Rhys restores Antoinette a real state of survival under colonialism and patriarchy, with a sense of identity loss and confusion. The use of symbolism is one of the most outstanding styles in description. Owing to the use of symbolism, the historical situation of Jamaica under colonialism and patriarchy has been successfully displayed and the abstract moral themes have been vividly conveyed. This paper seeks to set symbolism as a theoretical basis, classify and analyze the symbols in the novel in accordance with their roles in revealing the themes, illustrating a complete interpretation of the complicated racial conflicts and patriarchy oppression in West Indies.
\end{abstract}

Index Terms-Wide Sargasso Sea, symbolic reading, Jean Rhys

\section{INTRODUCTION}

Jean Rhys has established herself as one of the most remarkable novelists in the twentieth century. Her special personal background fosters her unique perspective of literary creation. Born in former British Caribbean colony and growing up there, Jean Rhys' novels focus on the life of Caribbean indigenous people, especially the miserable life of women under the oppression of the patriarchal society, and Wide Sargasso Sea is the best representative of these novels.

The unique novel, Wide Sargasso Sea, seeks to recreate the true story of Bertha Mason, the Jamaican mad wife of Rochester in Bronte's Jane Eyre (Rhys, 2001). Rhys wanted to explore the reasons why Bertha Mason went mad. In telling Bertha, or Antoinette's story, Rhys explores the colonial and patriarchal society that is conditioned by gender and race divisions, reflecting the oppression under colonialism and patriarchy and the identity crisis of the oppressed. The novel was honored with the prestigious W. H. Smith Award and the Heinemann Award of the Royal Society of Literature. It was also selected by Random House as one of the best one hundred books of fictions written in the English language during the twentieth century (Rhys, 2001).

Jean Rhys stands before her contemporaries by employing symbolism. The use of symbols, consisting of Sargasso Sea, the characters and the subjects, not only links the different parts but also intensifies the themes of the novel. Though she does get inspiration from Jane Eyre, Jean Rhys has surpasses it and established her reputation as "one of the most extraordinary novelists of our time. Wide Sargasso Sea succeeds in giving voice to a marginalized character and transforms her original tragic demise into a kind of triumphant heroism"(Gilbert, 1997, p.6-8).

The use of symbolism is one of the most outstanding styles in description. This paper attempts to focus on the symbolic technique used in Wide Sargasso Sea, from different angles simultaneously, in a detailed way, and somewhat systematically. Since one function of symbolism is to reveal the theme that in this particular novel is by describing Antoinette's tragic childhood and marriage failure to criticize the oppression of the colonialism, the patriarchy and compliment the resistant spirit of the oppressed. This paper tries to classify the symbols in Wide Sargasso Sea into three categories in accordance with their roles played in revealing the themes: the sense of identity, the racial conflicts and the patriarchal oppression. Accordingly, readers, in interpreting from symbolic perspective, could get closer to the essence of the world that the author depicted indirectly.

Introduction to Jean Rhys and Wide Sargasso Sea

Jean Rhys is described as "one of the greatest British writers of the $20^{\text {th }}$ century. Wide Sargasso Sea is the masterwork of Jean Rhys, in which she successfully corrects the wrong presentation of the madwoman in Jane Eyre, genuinely reflects the racial conflicts of Jamaican society in 1830s, bitterly criticizes the killing patriarchy, and narrates the embarrassing situation of the heroine who is caught between the European white and local black cultures, with a sense of identity loss and confusion.

\section{Jean Rhys}

Jean Rhys was born in Dominica in 1894. After her father died, she came to England aged 16 and drifted into various jobs before starting to write in Paris in the late 1920's, including chorus girl, mannequin and artist's model. She began to write while in her thirties and living in Paris following the break-up of the first of her three marriages. QUARTET was first published as 'Postures' in 1928. Her novels, often portraying women as underdogsout to exploit their sexualities, were ahead of their time and only modestly successful. From 1939 she lived reclusively, and was largely forgotten when she made a sensational comeback with 'Wide Sargasso Sea' in 1966, which won the Royal Society of Literature Award and the W. H. Smith Award for that year(www.amazon.co.uk). Her only comment on her sudden great success was "It has come 
too late". Her final collection of stories, Sleep It off Lady, appeared in 1976. In1978,she was made a Fellow of the Royal Society of Literature in 1966 and a CBE. She died in 1979.

These novels are about how women are aliens and they represent her bitter, insecure, revengeful feeling and her life outside of the conventional society. Rhys is adept at combining her personal experience with emotional and psychological insight to examine the nature of relationships between man and woman. In her works, she concentrates on complex, intelligent, sensitive women who are dominated by men and victimized by the colonial and patriarchal society.

\section{Wide Sargasso Sea}

Wide Sargasso Sea is a 1966 post-colonial parallel novel by Dominica-born author Jean Rhys. Since her previous work, Good Morning, Midnight, was published in 1939, Rhys had lived in obscurity. Wide Sargasso Sea put Rhys into the limelight once more, and became her most successful novel(Rhys, 2001).

Wide Sargasso Sea is composed with inspiration from Jane Eyre and has been thought of as a kind prequel to Jane Eyre, because it describes the childhood of Bertha Mason and the early days of her marriage, which are not described in Charlotte Brontë's novel. But it also does more than this.

Wide Sargasso Sea is about the story of the first Mrs. Rochester, Antoinette Cosway (known as Bertha Mason in Jane Eyre), a white Creole heiress, from the time of her youth in the Caribbean to her unhappy marriage and relocation to England. Caught in an oppressive patriarchal society in which she belongs neither to the white Europeans nor the black Jamaicans, Rhys' novel re-imagines Brontë's devilish madwoman in the attic. As with many post-colonial works, the novel deals largely with the themes of racial inequality and the harshness of displacement and assimilation(Rhys, 2001).

The novel is divided into three parts. Part one, narrated by Antoinette, focuses on her childhood at Coulibri after the death of her father, Alexander Cosway. In this part Antoinette's vague and fragmentary memories focus on glimpses of tropical landscape, description of her mother, and examples of her childhood isolation. Racial tensions and the disapproval of the white Jamaican pervade these memories. In the second part, young Rochester describes his arrival in the West Indies, his marriage and its disastrous aftermath. The last part is once more narrated by Antoinette, now called Bertha by Rochester; but the scene is now England, and she writes from the attic room in Thornfield Hall. There Antoinette recounts a dream that forecasts her burning of Thornfield and shields the candle to light her way along the dark passage(Rhys, 2001).

\section{Methodology}

It is obvious that symbolism is the main methodology in this paper. The use of symbolism is to classify and analyze the symbols in the novel in accordance with their roles in revealing the themes, illustrating a complete interpretation of the complicated racial conflicts and patriarchy oppression in West Indies.

\section{RESULTS AND ANALYSIS}

\section{A. Symbols Revealing Sense of Identity}

The term of "identity" here is an important post-colonial conception meaning "how we define who we are". And "as the process of decolonization continues, the growth of a national identity becomes highly important, particular in such a geographically divided region." (Wisker, 2000, p.96) Jean Rhys, because of her Creole identity and life experience, alienation from self and isolation from the outside world, features her work with a sense of identity crisis. Teresa F. O'Connor once observed "Rhys, herself caught between places and cultures, classes and races, never able to identify clearly with one another, gives the same marginality to her heroines, so that they reflect the unique experience of dislocation of the white Creole woman..." (O'Connor, 1986, p.9) Sargasso Sea and the mirror vividly tell a difficult way of identity loss and reconstruction.

For a certain individual, especially one born to parents of different nationalities, reared and educated in a different country and integrated into different cultures, the issue of identity is of great importance and has to be confronted. Antoinette characterized in Wide Sargasso Sea by Rhys is just such an example of women suffering from the loss of identity. Antoinette dwells in the most marginal place in the society, which is easy to be overlooked. Jean Rhys gives us the opportunity to have a look at the poor conditions of this minority group.

\section{Sargasso Sea: a symbol of the embarrassing situation of the heroine}

Sargasso Sea, because of the geographic location and the physical properties, stands a symbol revealing the embarrassment of our heroine. The Sargasso Sea is an extended region where is surrounded by ocean currents- the middle of the North Atlantic Ocean. The sea is different from the Atlantic Ocean, but it exists "in the heart of the Atlantic". The Sargasso Sea is the only sea without shores. It is physically defined by the "floating sargassum weed" and "a tremendous stillness". Sargasso Sea alludes to such embarrassing situation of Antoinette. She has no shores to harbor, as she has no particular culture or identity to pursue. She drifts between two cultures or identities.

Besides, the salty Sargasso Sea is usually treated as being lifeless, although it is home to some seaweed belongs to the genus sargassum. Because of its proximity to Bermuda, the sea is credited with some of the infamous disappearances there. That stigma is further enforced by the sometimes total lack of wind over the sea, and the possibility for modern engines to become entangled in the saragassum, stranding most vessels. Thus, it is sometimes called the "graveyard of ships" (Rhys,2001,p.3). Sargasso Sea once more alludes to such embarrassing situation of Antoinette. She is trapped and 
immobilized by a social structure and cannot escape.

Like Sargasso Sea, Antoinette drifts between two cultures. Her drifting predicament is caused by the European colonialism and the problems left by the colonialism. Sargasso Sea remains a perfect image for the impenetrable and gloomy problems of the dark voyage between West Indies and Europe. Antoinette is the Sargasso Sea that is "an image of feminine searching for autonomy and identity: although she struggles so hard, the woman never free herself from the insidious and invincible tentacles of exploiter and the patriarchal conditioning that cling to her as to try to find her way to herself." (Barat, 2001,p.40)

\section{Mirror: a symbol of pursuing and losing identity}

Characters in the novel frequently refer to mirrors as an external tool to assert their identity, turn to them for reassurance and conquer their fear. Mirrors as looking glasses, meaningful gazes and clear pool of water are embodiments, symbolizing the heroine's pursuing of identity.

Looking glass is often associated with women and their relationship with the society where their social status decides their identity. By looking their reflections in it, they hope to know about themselves and confirm self-image. Annette, when the family is rejected by the European whites, Annette "still planned and hoped-perhaps she had to hope every time she passed a looking glass." (Rhys, 2001, p.3) Dresses in fine clothing, Annette sees herself as a socialite in the looking class, hoping to identify her with the European whites and regain her lost status among peers.

In Wide Sargasso Sea, the physical mirror appears as an important symbol. In the first section of the novel, Antoinette is sent to the convent after experiencing the damage of the plantation, the death of her idiot brother, and the madness of her remarried mother. Without looking glass, Antoinette then has the relationship with outside cut up. There she finds "We have no looking-glass in the dormitory". (Rhys, 2001, p.30) The girls have no alternative but to look at themselves in a cask of water to build self-image. In another sense, no looking glass in the convent is to conceal her identity.

Years later Antoinette is enjailed in Thornfield, "there is no 1ooking-glass here and I don't know what I am like now. I remember watching myself brush my hair and how my eyes looked back at me. The girl I saw was me yet not quite myself. Long ago when I was a child and very lonely I tried to kiss her. But the glass was between us - hard, cold and misted over with my breath. Now they have taken everything away. What am I doing in this place and who am I?" (Rhys, 2001, p.116)

The statement mentions a important issue for identity again. Her English husband deprives her of chances to set up her identity by way of migrating to England and taking away the mirrors. So Antoinette totally lands herself in a predicament. The absence of a looking glass because it would offer her a reflection and a reassurance of herself. Mirrors underscore the important questions of identity. Antoinette, as her mother constantly looks for her own reflection, shows that they need to be visible in a world instead of acceptations or invitations. Antoinette was lonely put in a mirrorless prison and Rochester exacerbates her feeling of disconnection and loss of herself. Without a name, she does not know what to call herself; without a face, she becomes a ghost.

The last time Antoinette sees her reflection is in her dream, "I saw her-the ghost. The woman is with streaming hair. She was surrounded by gilt grime but I knew her." (Rhys, 2001, p.122) Years of imprisoned life has deformed her image and deprived of her identity, therefore, Richard Mason fails to recognize her and Antoinette fails to figure out herself in the looking glass either. She takes what she sees there as a ghost. Her failure to recognize herself in the 1ooking glass is the mark of a complete breakdown in her recognition of her own identity.

Tia, her black friend, provides Antoinette with a mirror reflection in gazing at each other. They eat the same food, sleep side by side and bathe in the same river. As Coulibri burns, Antoinette runs to Tia; she wants to live with her and be like her. She longs to be black and identify herself with the black culture. But "when I was close I saw the jagged stone in her hand but I did not see her throw it. I did not feel it either, only something wet, running down my face. I looked at her and I saw her face crumple up as she began to cry. We stared at each other, blood on my face, tears on hers. It was as if I saw myself, like in a looking glass." (Rhys, 2001, p.23) She fails to choose Tia's identity, for she calls Tia "you cheating nigger" and Tia replies "black nigger better than white nigger". The systematic supremacy and resentment and violence along the broader lines of contact between black and white make such a choice impossible. The stone thrown by Tia smashes the looking glass and shatters the possibility.

Tia emerges in her third dream, standing by the pool in Coulibri and beckoning to her. The pool of water is regarded as a looking glass and reflection of her image. The water is not like the glass, hard and cold, which prevent her uniting with the reflection. Antoinette becomes conscious that once she jumps into the water, she will tear up her present identity and rejoin with the black and Creole identity back in West Indies. In the end, fire symbolizes both destruction and creation. In burning Thornfield, Antoinette destroys "Bertha" but regains her original identity that has been deprived by Rochester, even at the price of life.

\section{B. Symbols Revealing Racial Conflicts}

In Jamaica, there were three types of race: the whites who controlled everything but made up only one percent of the population; the blacks who were mainly former slaves and the Creoles who belonged neither to the whites nor to the blacks. The Creoles was a special group on the islands. They were descendent of the former English, French or Spanish colonizers or slave-owners. They were born on the island, but belong to a class that has disappeared. After the emancipation of slaves in 1833 , slaves were not free. They have no land and become indentured servants for the whites. 
The conditions of the slaves are not better off. The conflict between the white and the enslaved natives in Jamaica is very severe.

Antoinette and her mother Annette, descendants of the former French colonizers, are born on the island but belong to a class that has disappeared. The blacks hate them because their ancestry is slave-owners. The European whites estrange from them since their home countries consider them inferior, believing that their pure blood of the superior Europe has been contaminated by the natives on the island. They are regarded as outsiders by both the blacks and the whites and are caught in between. Moreover, Christophine, a representative of the blacks, is colonized and considered as inferior by the whites, but she never stop claiming her voice in front of domination. The response of Christophine tells us that women can be oppressed, but never destroyed.

\section{Annette: a symbol of the Creole whites}

Annette is a symbol revealing racial conflicts as her tragic 1ife is caused by the clashes between the whites and the blacks, the European whites and the Creole whites. Annette is the second wife to Alexander Cosway and the mistress of the disused plantation, Coulibri Estate. Newly widowed, Annette Cosway has no male protector (except her retarded son, Pierre) and has no earning to support Coulibri. Whites born in England are different from the white Creoles, descendants of Europeans who have lived in the West Indies for one or more generations. What's worse, due to her beauty, just as Christophine says "because she pretty like pretty self," (Rhys, 2001, p.3) Annette has never been approved by the white Jamaican ladies.

Annette is original1y from Martinique which is a French colony. At that time, French and English had struggled for control of Dominica and other islands in the West Indies and this historical background makes her inferior in the eyes of the English women on the island. However, she still hopes to identify herself with the European society, "of course they have their own misfortunes. Still waiting for this compensation the English promised when the Emancipation Act was passed." (Rhys, 2001,p.3) Nevertheless, English promises of financial restitution do not materialize for a number of years. It is the act of abandonment by their own race that adds the extra edge of bitterness and despair. The family is marooned, indeed, since they are "white niggers" in the eyes of European whites. As a result, they are completely isolated in the society of Jamaica.

Against the background that the blacks are freed from the whites, the emancipation cannot change attitudes for so many years, and in fact, it releases a hatred of the blacks for the whites that have long been suppressed. Antoinette recalls "I never looked at any strange Negro. They hated us. They called us white cockroaches." (Rhys, 2001, p.7) Burrows put it this way "West Indian plantation fell into a state of ruin. The white Creole slave-owners were disowned by England and were openly hated by the newly freed slave." (Burrows, 2004, p.28-29)

The only thing Annette is proud of is to ride her horse about every morning. Though her riding clothes grow shabby, she doesn't care. But the black people stand about in groups to jeer at her, and even poison her horse. As she is pacing on the verandah of Coulibri, she is stared and laughed at by the passing blacks. Her body reflects the pain of her estrangement with her eyes shut and her hands clenched. A frown comes between her black eyebrows, so deep that it might have been cut with a knife: She becomes inward, cold and distant. Where is her way out?

Annette's Pierre dies, which is the last straw that completely destroys her. In grief she screams at Mason "Don't touch me. I'll kill you if you touch me. Coward, Hypocrite. I'll kill you." (Rhys, 2001, p.24) So she is labeled as losing wits and sent to two black caretakers. Later Christophine tells the truth. Annette becomes "mad" because she is driven to it. When she loses her son, she loses herself for a while, then she is shut away, "They tell her she is mad, they act like she is mad. Question, question. But no kind word, no friend. They won't let me see her. I try, but no. They won't let Antoinette see her. In the end-mad. I don't know - she gives up, she cares for nothing. That man who is in charge of her takes her whenever he wants..." (Rhys, 2001,p.102) Annette dies when Antoinette is in the convent school, which foretells that Antoinette is literally and completely left at the mercy of those forces which she can't stand a chance to escape.

Helen Tiffin explained, "The white Creole is, as a double outsider, condemned to self-consciousness, a sense of inescapable difference and even deformity in the two societies by whose judgment she always condemns herself." (Tiffin, 1978,p.328)

\section{Christophine: a symbol of the oppressed but rebellious blacks}

Christophine belongs to a class that is exploited and oppressed. But contrary to Annette, she is rebellious and undaunted. She is a symbol, standing for the native blacks and fighting against the domination and oppression. Christophine is a wedding gift to Annette by Antoinette's father. The name of Christophine is a symbolic one which indicates she is a Christ-like figure to Antoinette. Joseph reminds us of the earthly father of Christ in the Bible. When Antoinette is rejected by her mother, Christophine gives her love to Antoinette. When Antoinette is hurt, she gives her care. When Antoinette is in trouble, she gives her advice and help. It is she that tells Antoinette the importance of financial independence.

In spite of the fact that slavery has been abolished, the oppression of the blacks lingers for quite a long time, though not exactly in the form of slavery. In the minds of the whites, the black people have always been and are still a race of inferiority, fit only for subservient roles. When Christophine serves the coffee with her dress trailing on the floor, Rochester shows no approval, thinking it not a clean habit; though according to the black culture it is a good intention of showing respect.

The superiority of the whites over the blacks, in a way, can be manifested by their abuse of the black female bodies. On 
the one hand, they assert the black women are the vilest of the human kind, reducing them to animals. And any bodily contact with the blacks is thought to be threatening and disgusting; so Rochester has been wondering Why Antoinette would hug and kiss Christophine. Whereas, in Wide Sargasso Sea Christophine is an image of an incisive, perceptive and wise woman, whose influence permeates the entire novel. Her fierce pride and fearlessness have protected her from being appropriated by anyone, white or black. She is made to challenge and resist the European privilege and male authority.

Christophine is an image of an old woman with wisdom. She has keen intuitivism. She sees through the new methods of exploiting the workers, and the great wealth that the less scrupulous incomers could make. She sees through Rochester, knowing his intention to take advantage of Antoinette. She also forecasts Antoinette's marriage failure when the bride comes for love potion. She suggests Antoinette 1eave Rochester.

Christophine is portrayed as a brave fighter for justice. She denounces Rochester to his face that he is making use of Antoinette and maliciously destroys her and abandons her. When Antoinette nearly collapses after Rochester's revenge, Christophine steps up bravely and bitterly criticizes Rochester in her judge's voice, "Everybody know that you marry her for her money and you take it all. And then you want to break her up, because you jealous of her..." (Rhys, 2001, p.98) Rochester is overwhelmed by her imposing manner and in the last resort he threatens by mentioning calling the police. Even so, Christophine remains fearless and Rochester has to admit to himself her courage, "When I looked at her there was a mask on her face and her eyes were undaunted. She was a fight, I had to admit." (Rhys, 2001, p.105)

In all, Christophine and her fellow blacks, such as Daniel and Amelie, are continuously claiming their rights and fighting against the oppression. Their existence is always and forever a threat to the white colonizers.

\section{Symbols Revealing Patriarchal Oppression}

In the ideology of patriarchy society, the female is supposed to be feeble, subservient, reliant and submissive to the male, they are always exiled at the edge of the society by the dominant male sex. Men are regarded strong, rational and decisive, yet women are weak, irrational and submissive. Obviously there exist the gender inequality and discrimination.

In brief, patriarchy is a part of "the social organization is marked by the supremacy of the father in a clan or family, the legal wives and children with independence, and the male line with reckoning of descent and inheritance; it is broadly controlled by men with a disproportionately large share of power." Over a long term, patriarchy has been confined within feminism. Most forms of feminism have challenged patriarchy as a social system that is adopted uncritically, due to thousands of year's human history where male physical strength was the ultimate way of settling social conflicts - from war to disciplining children. In patriarchal system, wives, daughters as well as sisters are under the power and domination of fathers, husbands and brothers.

However, patriarchy is most likely to reflect a deeper expectations of formal male who is the dominance in a wide range of social relationships. Fredrika Scarth said, "Neither men nor women live their bodies authentically under patriarchy." (Scarth,2004,p.100) So in Wide Sargasso Sea, both the female characters, like Antoinette, Annette, Christophine, etc. and the male characters, such as Rochester and Daniel are also sufferers of patriarchal system. The differences lie in their different positions and different levels of torture. Among the characters, Antoinette and Rochester have strong symbolic meanings. Though they struggle, they can't escape the control of patriarchal system. On the contrary, Thornfield Hall stands for the stronghold of patriarchy.

\section{Antoinette: a symbol of women under patriarchy}

The first part of Wide Sargasso Sea established Antoinette's position as a marginalized and colonized people in a post-emancipation society. The second part is told from the perspective of Rochester, which is used to draw attention to the notion of the silenced female. Antoinette is pressed at the bottom of patriarchal system. She is the very typical symbol of patriarchal oppression, as it is shown in the following aspects: financial oppression and spiritual oppression. However, Antoinette doesn't stop resisting and at times she speaks out against the male power.

\subsection{Financial oppression}

Wide Sargasso Sea deals with the precarious financial dependence of women on man in the patriarchal colonized society. In such society, women are excluded from the center of power, and economically dependent on those in power. The decline in women's economic activity was linked to a decline in their social status because their economic dependence on men led to their subordination. Rhys explores her female characters' financial dependence on the men around them.

Antoinette loses her financial support; she loses her independence. She is a victim of a marriage without love, which is arranged by her step-father and step-brother. Anyone can easily relate her tragedy to Rochester, who as a younger son of an uncaring father is deserted and has always been tortured by his own inadequacies and his need to possess and to dominate. To get himself out of the domestic predicament, he successfully makes a financially advantageous match according to his father's plan and wishes. Although Antoinette hesitates for a time, her will is flabby as light as a feather. With Rochester's half-serious blandishments and promises, Antoinette gives away and accepts the marriage. Her thirty thousand pound dowry, in accordance with English 1aw, passes over to her husband. Antoinette becomes penniless and totally dependent on her husband. Without the financial independence, her independence is impossible.

According to English law, the wife relinquishes her property and all her possessions to her husband. After marriage, everything that at once belongs to the wife becomes the property of her husband. Mason gets the Coulibri Estate from Annette with the help of the law. The same way Rochester shall get Granbois from Antoinette in addition to the thirty 
thousand pound dowry. Without financial independence, she loses her wings to fly.

As time goes by, Rochester's ambition to control starts to predominate. The caution during his earlier stay is giving away and he starts to show his dissatisfaction with Antoinette's way of handling money, for "she handed out so carelessly, not counting it, not knowing how much she gave..." (Rhys, 2001,p.53) And soon their relation and position are reversed, it is Rochester who has seen to everything and arranged everything. Though Christophine once tells Antoinette the importance of financial independence, it seems Antoinette has been become completely dependent on her husband, for she is afraid that Rochester would be furious if she asks him for money. Antoinette, once the hostess of Granbois, now has lost control of a single penny and her independence stands no chance.

\subsection{Spiritual oppression}

Rochester has a strong desire to possess, to possess Antoinette's money and her spirit. At first, he comes all the long way to her house to beg her to marry. He deceives Antoinette by promising to give her happiness and safety, thus successfully gains her trust. Antoinette, then, can't help but love this man. She puts on the dress he likes. She cherishes the love so deep that she puts in her whole being. Bit by bit, Rochester has her in hand. But when he gets what he wanted, he totally becomes another person.

Things change when Rochester receives Daniel's 1etter. Daniel is the son of Mr. Cosway and a black servant. As a black Creole, he is denied the inheritance of his father, thus he has to struggle in that wicked world to find his own place. He vents out his wrath and hatred to Antoinette who marries a white man. His aim is to blackmail some money from Rochester, and vent out his wrath to the white. He tells Rochester that Rochester is tricked into a marriage with a girl of a "bad blood" and whose mother is a lunatic. This letter is the beginning of Rochester's denial of Antoinette. It is time to unfold his real feeling. He begins to alienate Antoinette, which he doesn't feel ill, for he has never loved her! Christophine sees through it: "When man don't love you, more you try, more he hate you, man like that." (Rhys, 2001, p.68)

But Antoinette has been controlled, fooled, and trapped, because she cannot leave her husband and she is chained to him by the concept that a woman should be loyal to her husband forever once she is married. She wants to clear up Daniel's rumors but is rejected by Rochester, "We won't talk about it now. Rest tonight. Not tonight. Some other time." (Rhys, 2001, p.81-82) The tone of Rochester is imperative. Antoinette is irritated, "you ask questions about my mother and then refuse listen to my answer." Therefore, as a colonial master, he suppresses the voice of Antoinette. The ability to speak for one is the power to assert one's identity and define one's existence in the world. Antoinette is constantly silenced by the dominant patriarchal and colonial power from then on. Antoinette is losing her voice.

Sandra M. Gilbert and SuSan Gubar investigated the relationship between women and madness. Mean while they also found that it had layers of meanings in their critical book -The Mad Woman in the Attic: the woman writer and the nineteenth-century literature imagination. "There were social and psychological reasons why women might go, or be considered, 'mad': women led restricted lives, their ambitions were often considered 'mad'. Their lives were in the hands of their husbands and male relatives. They could be locked up, divorced and deprived of their children and money if they were diagnosed 'mad'. (Jenkins, 2001,p.163)

\subsection{Antoinette's resistance}

Where there is oppression, there is resistance. Antoinette, however, instead of choosing to remain silent but keeps arguing with her husband to make her voice heard. Though Rochester tries greatly to conceal his dark side, he has no room to retreat under Antoinette's bitter lashing and scolding. He feels great threat and menace from her.

When Rochester and Antoinette talk about England, both insist that its own country is real while the other side is unreal. In the eyes of an English man, everything is unreal or inferior compared to Europe. However, Antoinette challenges his enrooted fallacy by refuting his country is unreal. Her voice is the voice of the other side. Rhys wants to tell us that always there is the other side and the voice of the other side should be heard.

Though confined in Thornfield, Antoinette doesn't lose her fighting will. In the end, she asserts the values of heat and light against the darkness. She sets fire to her confined prison, Thornfield Hall. The burning and destruction of this patriarchal castle symbolizes her release of preserved passion. The darkness is finally lighted by the rebellious fire. Walking towards her death, Antoinette is placid and calm. The calmness and easiness demonstrate her strength, her independence, her consciousness and spirit she will not allow Rochester to destroy or overpower.

\section{Rochester: a symbol of men under patriarchy}

It is a one-sided view that Rochester is a superior in the patriarchal system. He is victim too, for his father is superior to him and the father has the son's life in hand. Neither men nor women could live their bodies freely and independently under patriarchy. "a familial, social, ideological, system in which men - by force, direct pressure, or through tradition, law, language, determine what part shall or shall not play."(Ashcroft, 1989, p.89) The system not only "subsumes the female under the male, but also assumes the omnipotence-impotence relationship between father and son." (Yu,2005,p.88) Rochester is no exception from patriarchal control. He is also a typical symbol, telling us another story from a perspective different from the traditional feminism.

Rochester, as the youngest son of his family, is denied his share in his father's property. According to the law of primogeniture in England, all of his father's property goes to his elder brother. Therefore, he needs money to secure his social rank and status. At this very point, his

"Dear Father" arranges for him a marriage. O’Connor put it, "he experiences what it is like to be a woman". 
(O'Connor, 1986,p.98) The arranged marriage has placed him in the position of the female, without knowledge and without a sense of identity.

Rochester has no choice but go to the exotic West Indies to seek his fortune, with a great sense of loss. "Dear Father. The thirty thousand pounds have been paid to me without question or condition. No provision made for her (that must be seen to). I have a modest competence now."(Rhys, 2001, p.39) But it seems he isn't happy with the marriage, for he is kicked out of his family. He is nobody other than a burden (similar to Antoinette who is a burden to the Mason father and son). However, father's influence penetrates every inch of Rochester's world which is eating off, torturing him. Rochester, on the one hand, tries to escape from his father's effect; on the other hand, he can't keep himself away from his dependence upon it. After his talk with Daniel, he gets irritated. He takes on a mean attitude toward his "Dear Father", for he feels he is played.

He has hatred to his "Dear Father", he does want to revenge. But inside the patriarchy, he is impotent. In confrontation with his "Dear Father", he is a looser. He, thus, shifts his hatred to Antoinette, a Down in patriarchy, and transforms himself from victim into victimizer.

\section{Thornfield Hall: a symbol of the stronghold of patriarchy}

"Thornfield Hall" comes from Jane Eyre where "the depiction is used by Brontë who is aim to a manner being consistent with gothic in a tone of the novel as a whole." Under Brontë's pen, it is "an isolated mansion of unspecified size, with a number of apparently unused rooms". It becomes important to the narrative after the appearance of the madwoman - Bertha Mason. The name of the Hall expresses and amplifies the sense of depression and malaise.

"Thornfield" can literally be defined as a place where thorns grow. "Thorn" has its figurative meaning as "full of trouble and difficulties", so Thornfield conveys a strong sense of trouble, misery or distress. In Jane Eyre it symbolizes the miseries and hardships Jane has to come through before her ultimate happiness. But to Antoinette, it turns out to be her living hell.

Thornfield is the place where Antoinette is imprisoned by Rochester. It is the symbol of Rochester's wealth and patriarchal power. It can be compared to the patriarchal system that stifles Antoinette physically and spiritually. Confined in the dark and cold attic in Thornfield, Antoinette is situated in an insane and confused state, for she is unable to follow the passage of time and recognize the location. What left in her mind are fragmentary episodes of the isolated visual images. Thornfield Halls is doomed, for Rochester puts it, "Thornfield Hall-this accursed place - this tend of Achan - this insolent vault, offering the ghastliness of living death to the light of the open sky - this narrow stone hell, with its one real fiend, worse than a legion of such as we imagine." (Brontë, 1991, p.304)

In burning down Thornfield, Antoinette breaks out of the patriarchal system. The destruction of Thornfield is significant, because it is the way that leads her back to freedom. In destroying the tyranny of the patriarchy, Antoinette has taken revenge on the patriarchal society and her white oppressor and achieves her self-identity. The death of Antoinette is inevitable, she has to fulfill her job - destroying the stronghold of patriarchy, as M. Adjarian criticized, "although we know that Antoinette will leap to her death, Rhys draws us to see her active choice of death....as a liberating force of self-assertion." (Adjarian, 1995, p.90)

Contrast with Rochester's dissolution of self, Antoinette's remaining spirit is manifested by the fire of Thornfield Hall in the novel's last part. The fire is Antoinette's hope. It echoes the fire in Coulibri, as an outlet of hatred, and it is Antoinette's way of fighting against the patriarchal and empirical power. The fire of hatred is a proof of Antoinette's remaining spirit, which has not killed by Rochester. Thus, the fire symbolizes Antoinette's victory. In fire, Antoinette destroys the prison, burns herself and grasps the power to determine her own action and her own fate, thus she manages to express her rage, fulfill her revenge, find her identity and free her soul.

The destruction of Thornfield is highly symbolic. Since Thornfield is the place where Antoinette is imprisoned by Rochester and it is also the symbol of Rochester's power and wealth. Thornfield Hall can be compared to the patriarchal system that stifles Antoinette spiritually. In burning down Thornfield, Antoinette breaks out of patriarchal system. The destruction of Thornfield is significant, because it is the way that leads her back to her identity. Before she jumps from the roof, Antoinette sees the images of Tia. Calling Tia, she jumps to reunite with her. Thus it can be interpreted as her returning back to the local culture of West Indies. In destroying the tyranny of the patriarchal society, she has taken revenge on the patriarchal society and her white oppressor, and achieved her self-identity.

\section{Discussions AND CONCLUSIONS}

Jean Rhys is one of the greatest British women writers in the twentieth century. Wide Sargasso Sea which was published in 1966 at the end of Jean Rhys' writing career and reconsidered as the most successful of Rhys' literary works. The unique novel stands with special efforts, in which the outstanding Caribbean writer successfully writes back the classic Jane Eyre and gives voice to the muted madwoman and takes her from the margin to the center. Its publication has far-reaching effects and has won Jean Rhys extensive attention not only for her exploration in the post-colonialism and feminism, but also for her rare intelligence, great perception and unique style.

Rhys retells the story, rectifies the stereotypes of image imposed by European culture and reinterprets a granted conception of father superiority by giving the Downs a voice, letting them to tell their own stories. In doing so, Rhys not only corrects the distorted views of European on the natives of West Indies, but also subverts the Euro-centrism and male-centrism by confronting and contesting their domination and exploration. 
In this novel, as a post-colonial discourse, Rhys, by means of Sargasso Sea and the mirror, illustrates the hardship of Antoinette's losing and reconstructing her identity. Then, Rhys intends to demonstrate sharp racial conflicts in the West Indies after the Emancipation Act of Slavery, so she endows Annette and Christophine with symbolic meanings. Lastly, though Rhys once denied herself as a feminist, she is considered a pioneer to feminism. Antoinette and Rochester symbolically demonstrate the suffering of women and men in the patriarchal system and Thornfield Hall, on the contrary, is the embodiment of the patriarchy system.

The symbolic technique in Wide Sargasso Sea is more free, varied and meaningful, which plays a vital role in constructing and developing the plots. In this paper, the symbols are classified into groups in accordance with the functions in revealing the themes, providing a better and more explicit understanding of the novel. Thus, by virtue of symbolism, Rhys vividly depicts the historical situation of the West Indies in 1830s when people were suffering from both the imperial colonialism and the patriarchy, rendering Wide Sargasso Sea an admirable and worthy prequel to Charlotte Brontë's Jane Eyre. Symbolists believe that art should apprehend more absolute truths which could only be accessed indirectly. Jean Rhys' Wide Sargasso Sea is a case in point.

\section{ACKNOWLEDGEMENTS}

Upon the completion of this dissertation, I am indebted to many people who have offered great help in my writing of this paper. They have given me many excellent suggestions and assisted me generously with my paper-polishing. But for their invaluable advice as well as constant support, the completion of this paper would have been an impossible mission for me. Therefore, it is my pleasure to extend my gratitude to them.

My heartfelt thanks first go to my kind and encouraging supervisor, Zhu Xi, who has always been patient and instructive when I need academic advice. She has taken great pains reading different drafts of this paper and offered insightful comments and suggestions. It is Ms. Zhu who has helped me regain the confidence in myself; it is also her who set an example to me in my future life and career with her amiable disposition, professional skills and her enthusiasm for work.

I also feel obliged to my classmates and friends, whose great concerns and timely encouragement were of great importance to my paper writing.

Last but not least, I give special gratitude to my parents for their complete understanding, consistent encouragement and spiritual solace, and to those professors who dedicated their time and energy to reading my paper.

\section{REFERENCES}

[1] Burrows, Victoria. (2004). Whiteness and Trauma: the Mother-Daughter Knot in the Fiction of Jean Rhys. New York: Palgrave Macmillan.

[2] Carr, Helen \& Jean Rhys. (1996). Playmouth. England: Northolt House.

[3] CharlotteBront \& SongZhaolin. (2007). Jane Eyre. Shanghai: Shanghai Literature and Art Publishing House.

[4] Gilbert, Bart Moored. (1997). Post-colonial Criticism. London: Longman.

[5] Gregg, Veronica Marie. (1995). Jean Rhys' Historical Imagination: Reading and Writing the Creole. Chapel Hill: University of North Carolina Press.

[6] He Changyi. (2002). Marginalized female survival: who is the mad woman in Jane Eyre, Journal of Sichuan International Studies University, 3, 42-45.

[7] Howells, Coral Ann. (1991). Jean Rhys. New York: Harvester Wheat sheaf.

[8] James, Louis. (1978). Jean Rhys. London: Longman.

[9] Mardorossian, Carine. (2005). Reclaiming Difference: Caribbean Women Rewrite Post Colonialism. Charlottesville: University of Virginia Press.

[10] Mongia, Padmini. (1997). Contemporary Post-colonial Theory. London: Arnold.

[11] O'Connor, Teresa F. (1986). Jean Rhys: The West Indian Novels. New York: New York Press.

[12] Ramchand, Kenneth. (1970). The West Indian Novel and Its Background. London: Faber and Faber.

[13] Rees, Chen Liangting \& Liu Wenlan. (2001). Wide Sargasso Sea. Shanghai: Shanghai World Publishing Group.

[14] Rhys, Jean. (2001). Wide Sargasso Sea. Penguin Classics: Penguin Student Editions.

[15] Savory, Elaine. (1998). Jean Rhys. London: Cambridge University Press.

[16] Scarth, Fredrika. (2004). The Other Within: Ethics, Politics and the Body in Simone de Beauvoir. Oxford: Rowman \& Littlefield.

[17] Sun Ni. (2001). Joan Rees's life and works, Foreign Literature, 6, 15-19.

[18] Wang Zhiling. (2005). Bertha Mason - "mad woman" under the system of husband power, Appreciation of Famous Literature works, 1, 12-16.

[19] www.amazon.co.uk (accessed 29/2/2009).

Li Luo was born in Neijiang, China in 1989. She received her Bachelor Degree in English education from China West Normal University, Sichuan Nanchong, China in 2014. Importantly, she will receive her Graduate degree in Curriculum and teaching theory from China West Normal University, Sichuan Nanchong, China in 2019.

She is currently an English teacher in the Nanchong Staff University in China. Her research interests include English education, 
Teaching method and literature.

She is good at helping the students to get high scores and pass English exam due to her special teaching skills and methods which is written and concluded by herself. 